\title{
An improved method for calculating the regional crop water footprint based on a hydrological process analysis
}

\author{
Xiao-Bo Luan ${ }^{1,2, *}$, Ya-Li Yin ${ }^{3,}$, Pu-Te Wu ${ }^{2,3}$, Shi-Kun Sun ${ }^{1,3}$, Yu-Bao Wang ${ }^{1,3}$, Xue-Rui Gao ${ }^{3}$, and Jing Liu ${ }^{4}$ \\ ${ }^{1}$ Institute of Water Saving Agriculture in Arid regions of China, Northwest A \& F University, \\ Yangling, Shaanxi 712100, China \\ ${ }^{2}$ Institute of Soil and Water Conservation, Chinese Academy of Sciences and \\ Ministry of Water Resources, Yangling, Shaanxi 712100, China \\ ${ }^{3}$ Key Laboratory of Agricultural Soil and Water Engineering in Arid and Semiarid Areas, Ministry of Education, \\ Northwest A \& F University, Yangling, Shaanxi 712100, China \\ ${ }^{4}$ College of Hydrology and Water Resources, Hohai University, Nanjing, Jiangsu 210098, China \\ *These authors contributed equally to this work.
}

Correspondence: Pu-Te Wu (gjzwpt@vip.sina.com) and Shi-Kun Sun (sksun@nwafu.edu.cn)

Received: 12 March 2018 - Discussion started: 27 March 2018

Revised: 26 July 2018 - Accepted: 5 September 2018 - Published: 4 October 2018

\begin{abstract}
Fresh water is consumed during agricultural production. With the shortage of water resources, assessing the water use efficiency is crucial to effectively manage agricultural water resources. The water footprint is an improved index for water use evaluation, and it can reflect the quantity and types of water usage during crop growth. This study aims to establish a method for calculating the regional-scale water footprint of crop production based on hydrological processes, and the water footprint is quantified in terms of blue and green water. This method analyses the water-use process during the growth of crops, which includes irrigation, precipitation, groundwater, evapotranspiration, and drainage, and it ensures a more credible evaluation of water use. As illustrated by the case of the Hetao irrigation district (HID), China, the water footprint of wheat, corn and sunflowers were calculated using this method. The results show that canal water loss and evapotranspiration were responsible for most of the water consumption and accounted for $47.9 \%$ and $41.8 \%$ of the total consumption, respectively. The total water footprint of wheat, corn and sunflowers were 1380-2888, 942-1774 and 2095-4855 $\mathrm{m}^{3} \mathrm{t}^{-1}$, respectively, and the blue footprint accounts for more than $86 \%$. The spatial distribution pattern of the green, blue and total water footprints for the three crops demonstrated that higher values occurred in the eastern part of the HID, which had more precipitation and was further away from the irrigation gate. This study offers
\end{abstract}

a vital reference for improving the method used to calculate the crop water footprint.

\section{Introduction}

Human activities and climate change have serious effects on the availability of water resources (Nijssen et al., 2001; Haddeland et al., 2014). Agricultural production is major consumer of global water resources and accounts for $85 \%$ of the global blue water (surface or groundwater) consumption (Shiklomanov, 2000; Vörösmarty et al., 2010). In China, $63 \%$ of all water is used for agricultural production each year, and the area of irrigated farmland is $39.6 \%$ of the total arable land. Irrigation is the key to ensuring agricultural production (NBSC, 2016). With the rapid development of China's economy, the demand for water has increased in industrial production and in the lives of residents (Duh et al., 2008; Liu et al., 2008; Bao and Fang, 2012). Environmental pollution reduces water availability (Jiang, 2009; Schwarzenbach et al., 2010), and these changes place great pressure on regional water resources (Piao et al., 2010; Wang et al., 2014); meanwhile, climate change aggravates the situation (Elliott et al., 2014). With limited water resources, economic demand for water will inevitably and gradually take up the agricultural water use, which is a challenge for maintain- 
ing steady agricultural production (Chen, 2007; Khan et al., 2009), especially in the dry areas of northern China (Deng et al., 2006; Du et al., 2014). Strengthening agricultural water management and improving water use efficiency are significant aspects of handling water scarcity, and a reasonable evaluation of the water resource for crop production is the premise for developing an agricultural water management plan and implementing water-saving measures. Therefore, precisely evaluating the effective utilization ratio of current agricultural water use, improving the utilization efficiency and reducing the negative impact of the reduction of available agricultural water on agriculture production are important issues that all countries need to address globally, which are also of vital importance for ensuring food production and reducing the pressure on water resources. The water footprint theory provides new insights and ideas to solve these problems (Hoekstra, 2003). The water footprint is an indicator of freshwater use and can be used to quantify water consumption throughout the production supply chain. It reflects the amount of green, blue and grey water that is consumed (Hoekstra et al., 2011). In the agricultural sector, it can also be used to evaluate whether a crop's water footprint is reasonable and whether it varies regionally. Since green water can be used in agricultural production, some measures can be taken to reduce the water footprint of crop production, especially reducing the consumption of blue water, thereby easing the demand for blue water in agriculture. The accurate and precise quantification of the crop production water footprint is the premise to achieving the above goals.

Currently, based on two main methods proposed by Hoekstra et al. (2011), many scholars have quantified various levels of crop production water footprint, on a global level (Mekonnen and Hoekstra, 2011), a national level, such as Europe (Vanham and Bidoglio, 2013) and China (Zhao et al., 2009), and a regional level, such as Beijing (Sun et al., 2013a), Cremona province (Bocchiola, 2015) and Hetao (Luan et al., 2018). The first is the crop water requirement method (Cao et al., 2014; Sun et al., 2013c). This method simulates the actual evapotranspiration (ET) of crops under optimal conditions with the potential ET calculated by the Penman-Monteith Equation (Allen et al., 1998) and the effective precipitation calculation provided by the US Department of Agriculture Soil Conservation Service (USDA SCS) (Doll and Siebert, 2002). The green water consumption is the smaller value of total crop actual ET and effective precipitation. The blue water consumption is obtained from the difference between the total crops actual ET and effective precipitation. Finally, when combined with crop yields, the crop blue and green water footprint $\left(\mathrm{m}^{3} \mathrm{t}^{-1}\right)$ can be calculated. The second is the irrigation schedule method. This method is based on an empirical formula model such as the CROPWAT model (FAO, 2010; Mekonnen and Hoekstra, 2011) CropSyst (Bocchiola et al., 2013), the Environmental Policy Integrated Climate (EPIC) model (Shi et al., 2017), the GISbased model GEPIC (Liu et al., 2007) and the AquaCrop model (Pasquale et al., 2009; Chukalla et al., 2015; Zhuo et al., 2016). The detail calculation process of these two methods are listed in the Supplement.

These methods can simulate actual ET throughout the crop growing period according to the soil water balance under optimal or suboptimal conditions. The blue water consumption is the smaller value of net irrigation water and the net irrigation water requirement. The green water consumption is equal to the total actual ET minus blue water. Both of the above methods are based on empirical formulas. A few scholars have attempted to calculate the regional-scale water footprint; for example, Sun et al. (2013b) used the difference between diversion and drainage to calculate the water footprint of crop production in irrigated areas. However, these methods have certain shortages, which are as follows:

First, the applicability of the empirical method has not been determined, that is, whether the method is applicable to the field scale or regional scale of the water footprint calculation needs further study. These methods calculated the fieldscale water footprint with net irrigation water considered as irrigation water and without considering water loss during transport, which definitely serves crop growth. Therefore, these methods are field-scale methods, whereas a regionalscale method should include the aforementioned two losses. At present, irrigation water mainly refers to the net irrigation water used by crops in the field. Current irrigation water analysis methods have not considered water loss during water delivery and drainage. Therefore, the calculation of the water footprint at the field scale cannot be accurately applied to irrigated agriculture. However, there are still few methods to calculate the water footprint on the regional scale.

Second, the irrigation data in these methods are simulation values and not based on the actual irrigation time and irrigation quota (the amount of water demanded for crop irrigation); therefore, these data cannot reflect the real situation of the local water usage due to the incomplete simulation data. At the same time, the traditional method does not completely analyse the water footprint components of water resources in the process of water diversion, water transfer, irrigation and drainage.

Third, the current regional-scale method has not been appropriately established. The method that Sun et al. (2013b) used had the aforementioned limitations. It included all of the water consumption, but it could not distinguish the specific source of blue water from canal loss, field actual ET or groundwater. Due to its low spatial resolution, only the water footprint of the entire irrigated area could be calculated instead of the difference inside this area.

Currently, most studies focus on the field scale and lack a systematic evaluation of the whole process of water consumption during crop growth. To overcome this problem, this study put forward an improved regional-scale calculation method of the crop water footprint based on a hydrological process analysis and used it to quantify the crop water footprint in the Hetao irrigation district (HID). This method sim- 


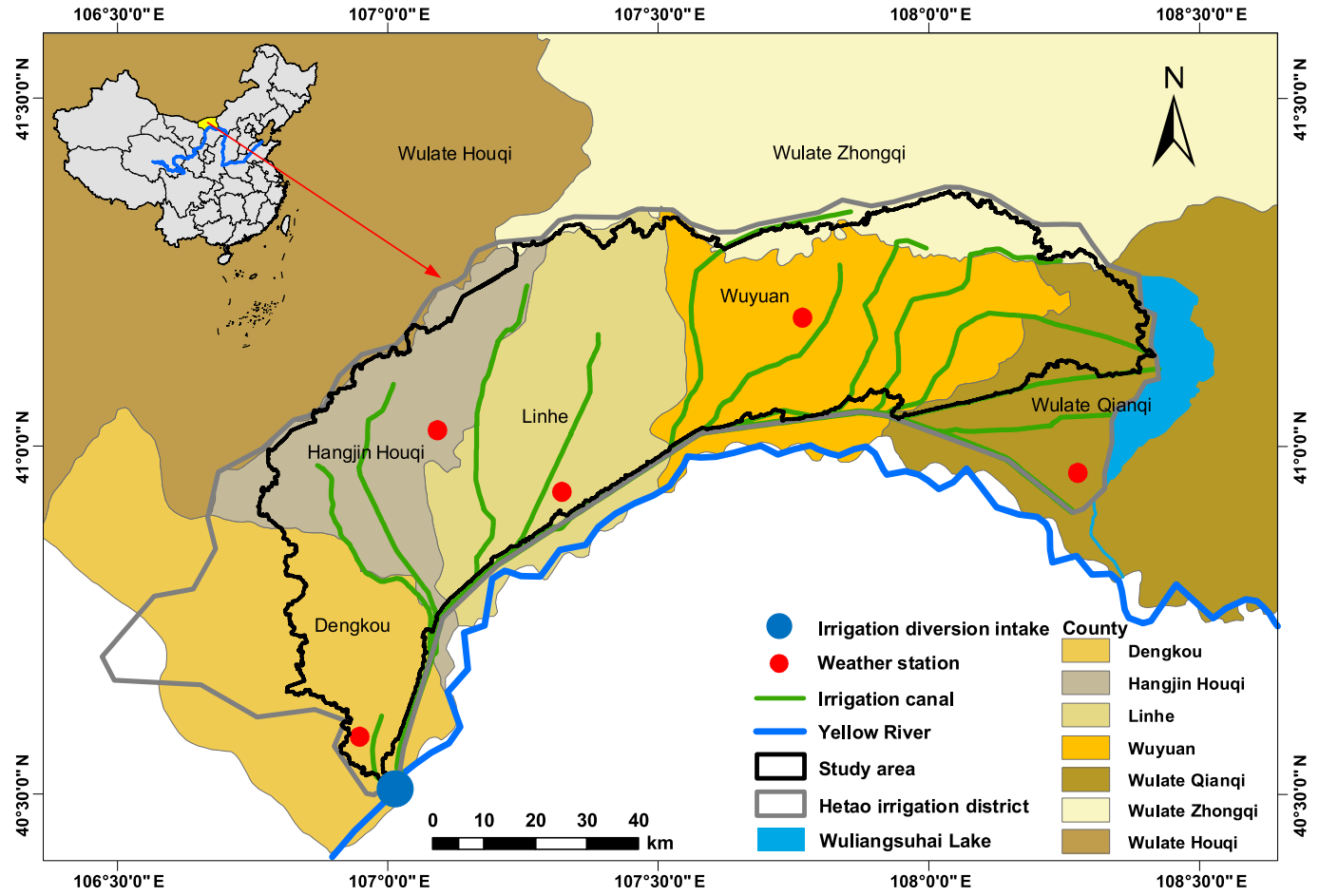

Figure 1. Location of the Hetao irrigation district (HID) in China.

ulated the hydrological cycle of the region based on a physical hydrological model using the soil and water assessment tool (SWAT). Based on the method, this study analysed the water input and output during crop production, and calculated the water consumption in crop growth, field drainage and water loss during canal water transport. Combined with crop yields, the water footprint of crop production at the regional scale was quantified. This method will provide comprehensive information for the analysis of water consumption during crop production process and improve the spatial resolution of the regional distribution of the water footprint of crop production.

\section{Materials and methods}

\subsection{Study site}

The Hetao irrigation district (HID) is located in the middle of the Yellow River basin in western Inner Mongolia (Fig. 1) and is one of the three largest irrigation districts in China. The HID has a continental monsoon climate with the lowest temperatures in January (average $-10^{\circ}$ ) and the highest temperatures in July (average $23^{\circ}$ ). The average monthly precipitation is $37.5 \mathrm{~mm}$ (May to September), $3.4 \mathrm{~mm}$ (October to April of the next year), and the average monthly potential evaporation is $290.6 \mathrm{~mm}$ (April to September), $77.2 \mathrm{~mm}$ (October to March of the next year). The area of the HID is $1.12 \times 10^{4} \mathrm{~km}^{2}$.
Irrigation water is diverted from the Yellow River. The irrigation and drainage systems in the HID are composed of irrigation canals and drainage ditches; the irrigation system has a general main canal $(228.9 \mathrm{~km})$ and 12 main canals (total $755 \mathrm{~km}$ ), and the drainage system has a general main ditch $(227 \mathrm{~km})$ and 12 main ditches (total $523 \mathrm{~km})$. The main crops include wheat, corn and sunflowers (Fig. 1).

\subsection{Model description}

The SWAT model is a semi-distributed physical hydrological model. The model was developed by the USDA Agricultural Research Center, and it uses climate, soil, topography, plants and land management practises to simulate the hydrologic, sediment, crop growth and nutrient cycle. The model partitions a watershed into sub-basins by topography and then partitions the sub-basins into hydrologic response units (HRU) based on soil type and land use to assess soil erosion, non-point pollution and hydrologic processes (Haverkamp et al., 2002). The water balance equation governed by the hydrologic component of the SWAT model (Neitsch et al., 2011) is as follows:

$\mathrm{SW}_{t}=\mathrm{SW}_{0}+\sum_{i=1}^{t}\left(R_{\text {day }}-Q_{\text {surf }}-E_{\mathrm{a}}-W_{\text {seep }}-Q_{\mathrm{gw}}\right)$,

where $\mathrm{SW}_{t}$ is the final soil water content $\left(\mathrm{mm} \mathrm{H}_{2} \mathrm{O}\right), \mathrm{SW}_{0}$ is the initial soil water content $\left(\mathrm{mm} \mathrm{H}_{2} \mathrm{O}\right), t$ is the time (days), $R_{\text {day }}$ is the amount of precipitation on day $i\left(\mathrm{~mm} \mathrm{H}_{2} \mathrm{O}\right)$, 
Table 1. Data used in the study and the resources.

\begin{tabular}{|c|c|c|c|}
\hline Dataset & Data description & Resolution & Data sources \\
\hline DEM & - & $30 \times 30 \mathrm{~m}$ & Geospatial data cloud (CAS, 2009a) \\
\hline Soil & $\begin{array}{l}\text { Soil type map, } \\
\text { soil physical and chemical } \\
\text { properties }\end{array}$ & $1: 1000000$ & $\begin{array}{l}\text { China Soil Scientific Database (CAS, } \\
\text { 2009b) }\end{array}$ \\
\hline Land use & - & $\begin{array}{l}1: 100000 \\
(2010)\end{array}$ & $\begin{array}{l}\text { Data Center for Resources and } \\
\text { Environmental Sciences (CAS, 2010) }\end{array}$ \\
\hline Weather & $\begin{array}{l}\text { Precipitation, wind speed, } \\
\text { solar radiation, } \\
\text { maximum temperature, } \\
\text { minimum temperature, } \\
\text { relative humidity }\end{array}$ & $\begin{array}{l}\text { Daily } \\
(1980-2012)\end{array}$ & $\begin{array}{l}\text { China Meteorological Data Network } \\
\text { (NMIC, 2015) } \\
\text { The Administration of Hetao irrigation } \\
\text { district (AHID, 2015) }\end{array}$ \\
\hline Hydrologic & $\begin{array}{l}\text { Stream map, } \\
\text { discharge }\end{array}$ & $\begin{array}{l}\text { Monthly } \\
\text { (2003-2012) }\end{array}$ & $\begin{array}{l}\text { The Administration of Hetao irrigation } \\
\text { district (AHID, 2015) }\end{array}$ \\
\hline $\begin{array}{l}\text { Crop } \\
\text { parameter } \\
\text { data }\end{array}$ & $\begin{array}{l}\text { Dates of plant and harvest, } \\
\text { dates of irrigation, } \\
\text { irrigation quota }\end{array}$ & - & $\begin{array}{l}\text { The Administration of Hetao irrigation } \\
\text { district (AHID, 2015) }\end{array}$ \\
\hline
\end{tabular}

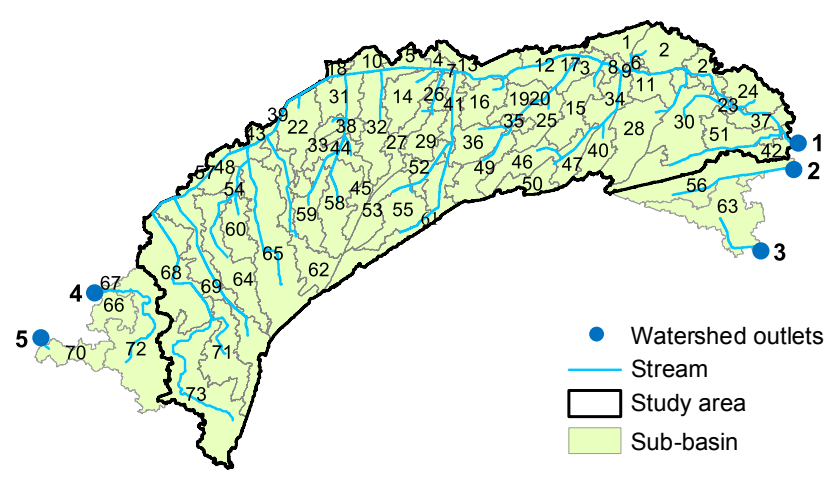

Figure 2. Sub-basins and study areas.

$Q_{\text {surf }}$ is the amount of surface runoff on day $i\left(\mathrm{~mm} \mathrm{H}_{2} \mathrm{O}\right)$, $E_{\mathrm{a}}$ is the amount of actual ET on day $i\left(\mathrm{~mm} \mathrm{H}_{2} \mathrm{O}\right), W_{\text {seep }}$ is the amount of percolation and bypass flow exiting the bottom of the soil profile on day $i\left(\mathrm{~mm} \mathrm{H}_{2} \mathrm{O}\right)$, and $Q_{\mathrm{gw}}$ is the amount of return flow on day $i\left(\mathrm{~mm} \mathrm{H}_{2} \mathrm{O}\right)$.

\subsection{Data collection}

The data required by the SWAT model includes a digital elevation model (DEM), soil data, land use and hydrological and climate data (Table 1). The climate data were obtained from five weather stations in the HID.

The water efficiency of the canal system in this model was obtained from local agricultural administrations (AHID, 2015). To divide the sub-basins, we defined the drainage ditch as the stream (AHID, 2015) and burn-in into the DEM, and the simulation results were verified by the discharge of the drainage ditch.

The model generated five outlets and 73 sub basins, and the measured data of the first outlet in the study area were ob- tained (Fig. 2). Therefore, this study chose the area controlled by this outlet as the study area. The crops' yields (wheat, corn and sunflowers) required for the calculation of the water footprint were obtained from the statistical yearbook of the local agricultural administrations (AHID, 2015).

\subsection{Calibration and validation}

The sequential uncertainty fitting (SUFI-2) algorithm in SWAT Calibration and Uncertainty Programs (SWAT-CUP) was applied for calibration and validation (Abbaspour et al., 2007; Abbaspour, 2012) by comparing the simulated stream discharge from the model with the measured discharge data. The global sensitivity analysis integrated in SUFI-2 was used to evaluate the hydrologic parameters for the discharge simulation, and then the optimal simulation was established by adjusting the sensitivity parameters and through multiple iterations. The calibration period was from 2006 to 2009, and the validation period was from 2010 to 2012. The result of the SWAT calibration and validation process is satisfactory, and the detailed process is available in the Supplement.

\subsection{The regional-scale water footprint calculation method}

Based on the water footprint theory framework provided by Hoekstra et al. (2011), this study suggests a new way of quantifying the regional-scale water footprint of crop production (Fig. 3).

In this study, green water consumption is the effective precipitation during the crop growth process. Blue water consumption includes canal water loss during delivery, the ET produced by consumption of irrigation water and groundwater for crops growth, and the drainage in the fields. To calculate the canal water loss, an extra model needs to be estab- 
lished according to the HID situation, and the other can be simulated and obtained by the SWAT model.

\subsubsection{Calculation of water consumption factors in the fields}

Water consumption in the fields consists of four parts, including the actual ET of precipitation, irrigation water, groundwater utilised by crops and field drainage. This study set up two scenarios and calculated the above water consumption by changing the sources of water in the SWAT model. In scenario 1 (S1), crop water consumption was derived from precipitation and irrigation water (irrigation systems and irrigation quotas are based on local irrigation methods), i.e. the actual situation of crop water use. In scenario 2 (S2), crop water consumption was only derived from precipitation without irrigation. The $\mathrm{S} 2$ was used to calculate the consumption of green water. In this study area (HID), because of less rainfall, the effective precipitation formed by precipitation events is all used for crop growth. Therefore, the consumption of green water for crops is equal to the effective precipitation, which means that green water is reflected by calculating the effective precipitation stored in soil by the SWAT model. The calculation formula is as follows.

$$
\begin{aligned}
& \mathrm{WF}=\mathrm{WF}_{\mathrm{g}}+\mathrm{WF}_{\mathrm{b}}=\frac{W_{\mathrm{g}}}{Y}+\frac{W_{\mathrm{b}}}{Y}, \\
& W_{\mathrm{g}}=\mathrm{PRECIP}_{\mathrm{s} 2}-\mathrm{SUPQ}_{\mathrm{s} 2}-\mathrm{LATQ}_{\mathrm{s} 2}, \\
& W_{\mathrm{b}}=Q_{\mathrm{c}}+Q_{\mathrm{f}}+Q_{\mathrm{d}}, \\
& Q_{\mathrm{c}}=I_{\mathrm{t}, \mathrm{s} 1}-I_{\mathrm{f}, \mathrm{s} 1}=\frac{I_{\mathrm{f}, \mathrm{s} 1}}{k_{\mathrm{s} 1}}-I_{\mathrm{f}, \mathrm{s} 1}, \\
& Q_{\mathrm{f}}=\mathrm{ET}_{\mathrm{s} 1}-W_{\mathrm{g}}, \\
& Q_{\mathrm{d}}=\mathrm{WYLD}_{\mathrm{s} 1},
\end{aligned}
$$

where WF is the water footprint of crop production $\left(\mathrm{m}^{3} \mathrm{t}^{-1}\right)$, $\mathrm{WF}_{\mathrm{g}}$ is the green footprint $\left(\mathrm{m}^{3} \mathrm{t}^{-1}\right), \mathrm{WF}_{\mathrm{b}}$ is the blue water footprint $\left(\mathrm{m}^{3} \mathrm{t}^{-1}\right), W_{\mathrm{g}}$ is the green water consumption during the crop growth period $\left(\mathrm{m}^{3}\right), W_{\mathrm{b}}$ is the blue water consumption during the crop growth period $\left(\mathrm{m}^{3}\right), Y$ is the crop yield (t), PRECIP $\mathrm{s}_{2}$ is the precipitation during the crop growth period in Scenario $2\left(\mathrm{~m}^{3}\right), \mathrm{SUPQ}_{\mathrm{s} 2}$ is the surface runoff during the crop growth period in Scenario $2\left(\mathrm{~m}^{3}\right)$, LATQ $_{s 2}$ is the soil lateral flow during the crop growth period in Scenario $2\left(\mathrm{~m}^{3}\right), Q_{\mathrm{c}}$ is the amount of water loss in the canal system $\left(\mathrm{m}^{3}\right), Q_{\mathrm{f}}$ is the actual ET of field irrigation water $\left(\mathrm{m}^{3}\right), Q_{\mathrm{d}}$ is the field discharge $\left(\mathrm{m}^{3}\right), I_{\mathrm{t}, \mathrm{s} 1}$ is the total amount of irrigation water diversion in Scenario $1\left(\mathrm{~m}^{3}\right)$ and $I_{\mathrm{f}, \mathrm{s} 1}$ is the actual amount of water irrigated in the field in Scenario $1\left(\mathrm{~m}^{3}\right) . k_{\mathrm{s} 1}$ is the effective utilization coefficient of canal water in Scenario 1 (obtained from the local water resource management department), $\mathrm{ET}_{\mathrm{s} 1}$ is the crop actual ET during the crop growth period in Scenario $1\left(\mathrm{~m}^{3}\right)$ and WYLD $_{\mathrm{s} 1}$ is the total amount of water leaving the HRU in Scenario $1\left(\mathrm{~m}^{3}\right)$. The data of parameters PRECIP $_{\mathrm{s} 2}, \mathrm{SUPQ}_{\mathrm{s} 2}$,
$\mathrm{LATQ}_{\mathrm{s} 2}, I_{\mathrm{t}, \mathrm{s} 1}, \mathrm{ET}_{\mathrm{s} 1}$ and $\mathrm{WYLD}_{\mathrm{s} 1}$ were obtained from the SWAT model.

\subsubsection{Calculation of water loss during delivery}

Water transfer loss is a kind of water loss in the process of channel water delivery, and it is an important part of blue water consumption in crop production. For a piece of cultivated land, the water loss during the process of the crop production includes the loss of water from the water source to the field, flowing through the canal system. In the Hetao irrigation district, the irrigation canal is composed of seven grades (general main canal, main canal, sub-main canal, branch canals, lateral canals, field canals and sub-lateral canals) because of the complex distribution of canal system and the lack of hydrological data in irrigation districts (the lack of an effective utilization coefficient of canal water below the main canal). Therefore, in calculating the water loss of canal system during crop production process, we generalised the Hetao irrigation district into a model similar to the histogram (Fig. 4).

We divide the total water loss of canal system into two parts. Part A is the loss of the main canal and canal, and Part B is the loss of the remaining canal system (the water loss of the sub-main canal and its sub-channels at all levels). The calculation of water loss in Part A is as follows; first, the water loss of each section is calculated by dividing the main canal into equal distances $(10 \mathrm{~km})$. Then the water transfer loss of each section of the canal is allocated to each field downstream (Eq. 10), thereby obtaining the water transfer loss in the crop production process on the field block. Therefore, the actual water loss caused by irrigation in a field is the sum of the water loss of the transfer canal and the canal in the upstream. We assign the actual water loss of the field by irrigation $\left(Q_{j i}\right.$, Eq. 11) to the midpoint of each section, and use Kriging interpolation in ArcGIS to obtain the water loss distribution map of the figure a (Part A).

Due to the lack of the effective utilization coefficient of canal water and the distribution map of the canals at all levels and below, the calculation process of the water loss in Part B is as follows; the remaining canal loss in each irrigation canal is divided by the main canal irrigation and the unit area loss of the canal control area is obtained. Then, the amount of water loss per unit area within the control range of each main canal in the irrigation area $\left(Q_{j}\right.$, Eq. 15) is obtained, and the data are brought into ArcGIS for the water loss distribution map of figure b (Part B). Finally, the figure a and the figure $\mathrm{b}$ are superimposed and calculated in the ArcGIS using the map algebra module of the spatial analysis tool to obtain the water loss distribution map of the canal system in HID. The formulas are as follows:

$$
\begin{gathered}
Q_{j i}=W_{j n} \times\left(\frac{1}{n}+\frac{1}{n-1}+\cdots+\frac{1}{n-(i-1)}\right) \\
j \in(1,2,3, \cdots, m) i \in(1,2,3, \cdots, n),
\end{gathered}
$$




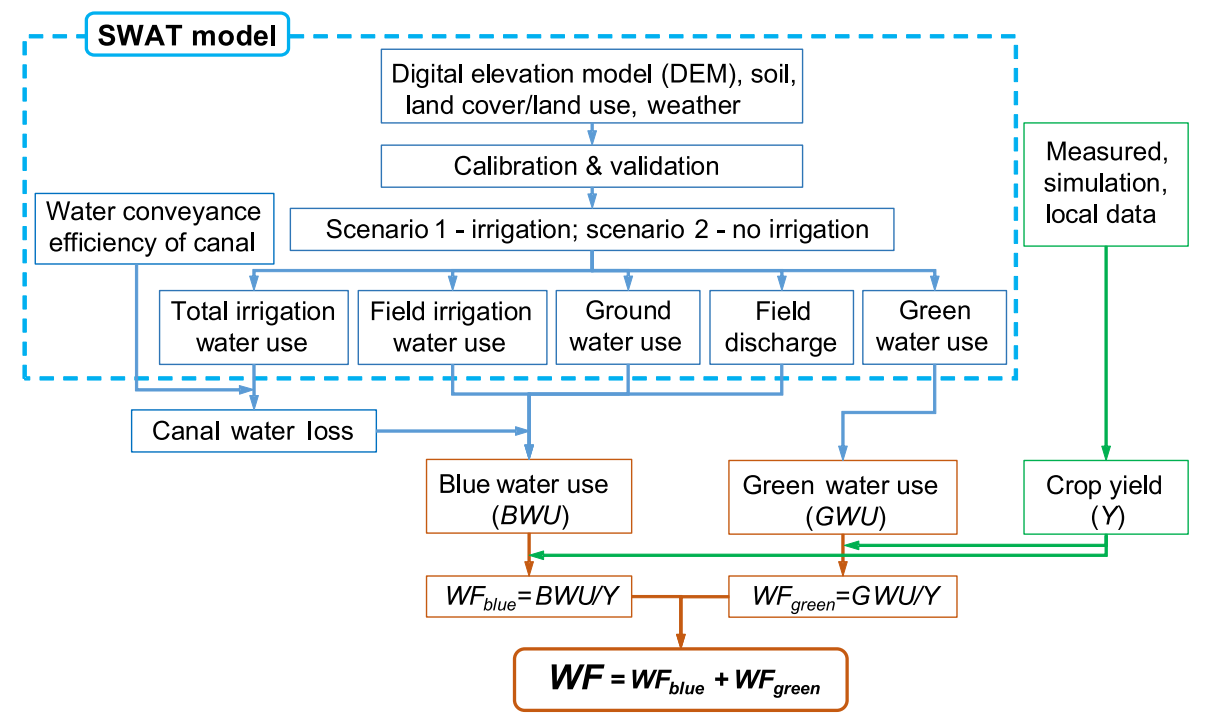

Figure 3. The flow chart for calculating the regional-scale water footprint.

$W_{j n}=\frac{W_{\mathrm{A}} \times k_{j}}{n \times S_{j n}}$,

$W_{\mathrm{A}}=I_{\mathrm{t}, \mathrm{s} 1} \times\left(1-k_{\mathrm{gc}} \times k_{\mathrm{mc}}\right)$,

$S_{j n}=\frac{S_{j}}{n}$,

$Q_{j}=\frac{W_{\mathrm{B}} \times k_{j}}{S_{j}}$,

$W_{\mathrm{B}}=Q_{\mathrm{c}}-W_{\mathrm{A}}$,

where $Q_{j i}$ is the actual amount of water loss per unit area of the $i$ section of the $j$ th main canal in Part $\mathrm{A}\left(\mathrm{m}^{3} \mathrm{ha}^{-1}\right)$, $W_{j n} \mathrm{~s}$ the water loss per unit area of the section of the $j$ th main canal in Part $\mathrm{A}\left(\mathrm{m}^{3} \mathrm{ha}^{-1}\right), j$ is the number of the main canal, $i$ is the number of the equidistance sections in the $j$ th main canal, $n$ is the total number of the sections in the $j$ th main canal, $m$ is the total number of the main canals, $W_{\mathrm{A}}$ is the amount of water loss in Part $\mathrm{A}\left(\mathrm{m}^{3}\right), k_{j}$ is the coefficient of the water distribution from the general main canal to the $j$ th main canal, $S_{j n}$ is the area of each section in the $j$ th main canal (ha), $I_{\mathrm{t}, \mathrm{s} 1}$ is the amount of total irrigation water diversion in Scenario $1\left(\mathrm{~m}^{3}\right), k_{\mathrm{gc}}$ is the water conveyance efficiency of the general main canal, $k_{\mathrm{mc}}$ is the water conveyance efficiency of the main canal, $S_{j}$ is the area controlled by the $j$ th main canal (ha), $Q_{j}$ is the water loss per unit area of the $j$ th main canal in Part B $\left(\mathrm{m}^{3} \mathrm{ha}^{-1}\right), W_{\mathrm{B}}$ is the amount of water loss in Part B $\left(\mathrm{m}^{3}\right)$ and $Q_{\mathrm{c}}$ is the amount of water loss in the canal system $\left(\mathrm{m}^{3}\right)$.

Note that $S_{j n}$ is the area of each section in the $j$ th main canal, $W_{j n}$ is the water loss per unit area of the section of the $j$ th main canal in Part A, $Q_{j i}$ is the actual amount of water loss per unit area of the $i$ section of the $j$ th main canal, $S_{j}$ is the area controlled by the $j$ th main canal, $k_{j}$ is the coefficient of the water distribution from the general main canal

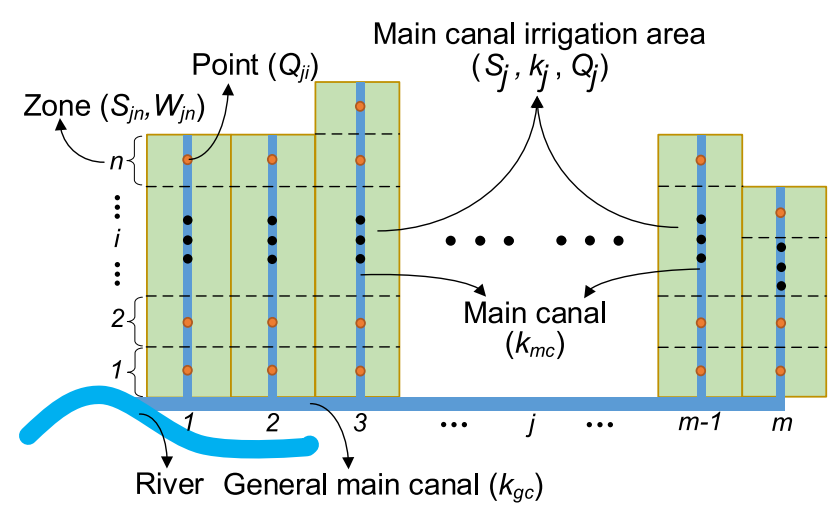

Figure 4. Model for the calculation of water loss in the canal system.

to the $j$ th main canal, $Q_{j}$ is the water loss per unit area of the $j$ th main canal in Part $\mathrm{B}, k_{\mathrm{gc}}$ is the water conveyance efficiency of the general main canal, $k_{\mathrm{mc}}$ is the water conveyance efficiency of the main canal, $j$ is the number of the main canal, and $i$ is the number of the equidistance sections in the $j$ th main canal.

\section{Results}

\subsection{Analysis of the process of crop production and the quantification of hydrological elements in each link}

Figure 5 shows the average water input and consumption of the study area in the process of water diversion, transportation, irrigation and drainage from 2006 to 2012. In HID, the water input for irrigation for the three crops in the study area was $3177 \times 10^{6} \mathrm{~m}^{3}$, water loss during transporta- 


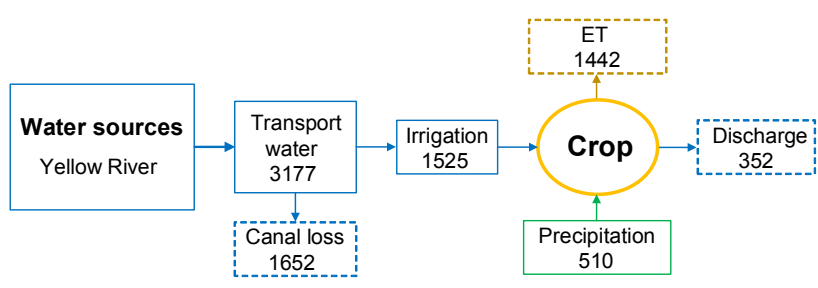

Figure 5. The amount of water during crop growth $\left(\times 10^{6} \mathrm{~m}^{3}\right)$.

tion in the canals was $1652 \times 10^{6} \mathrm{~m}^{3}$, the actual field irrigation water was $1525 \times 10^{6} \mathrm{~m}^{3}$, precipitation in the farmland was $510 \times 10^{6} \mathrm{~m}^{3}$, the actual ET of the farmland was $1442 \times 10^{6} \mathrm{~m}^{3}$, the field discharge was $352 \times 10^{6} \mathrm{~m}^{3}$ and the groundwater was not considered because the consumption was small. Precipitation and irrigation are the water input items in the process of crop production, and the canal water loss, field actual ET and field drainage are the water output items. For water input, precipitation and irrigation accounted for $25.1 \%$ and $74.9 \%$, respectively. For the water output, channel water loss, field actual ET and field drainage accounted for $47.9 \%, 41.8 \%$ and $10.3 \%$, respectively. Irrigation is the main water source in the irrigated district, and the water loss in the canals and actual ET are the main water output in the irrigated district.

Green water is the precipitation used for crop growth; therefore, the green water footprint is highly correlated with precipitation in its growth period. Wheat's growth period is from April to July, whereas that of corn and sunflowers is from May to September. During the growth period of wheat, the mean precipitation from 2006 to 2012 was $108.9 \mathrm{~mm}$, and for corn and sunflowers, the corresponding mean precipitation was $176.1 \mathrm{~mm}$. The green footprint of wheat during the growth period was lower than that of corn and sunflowers because of the lower mean precipitation in the wheat growth period. The green water consumption of corn was close to the value of the sunflower. The average green water consumption of wheat, corn and sunflowers were 895,1441 and $1419 \mathrm{~m}^{3} \mathrm{ha}^{-1}$ (Fig. 6a1-c1), respectively. Meanwhile, green water consumption in the high precipitation area was larger; for instance, the precipitation during the wheat growth period in Wuyuan reached $116.3 \mathrm{~mm}$, and the green water consumption in this region was the largest (up to $995 \mathrm{~m}^{3} \mathrm{ha}^{-1}$ ). In the growth period of corn and sunflowers, the precipitation in Wulate Qianqi reached $199.4 \mathrm{~mm}$, and the green water consumption in this area was again the largest, reaching 1785 and $1765 \mathrm{~m}^{3} \mathrm{ha}^{-1}$, respectively.

Blue water is the surface water used for crop growth in this study. In blue water consumption, the farther away from the watershed inlets, the longer the canal was and the larger the water loss of the three crops. Northeast of the irrigation area (parts of Wuyuan and Wulate Qianqi) and due to the far distance from watershed inlets, canal water loss in these places was much higher than that in other areas, and the maximum canal water loss of wheat, corn and sunflowers reached 8977 , 8929 and $9951 \mathrm{~m}^{3} \mathrm{ha}^{-1}$, respectively.

The actual ET and the discharge of the three crops was higher in the east than in the west, which was due to the higher evaporation in the east than in the west. Meanwhile, Fig. 6 shows that the actual ET in the field was complementary with discharge. The higher the actual ET, the smaller the discharge and vice versa.

\subsection{The regional green-water footprint of crop production}

The spatial difference of the green water footprint of wheat, corn and sunflowers in HID was obvious (Fig. 7). It can be seen from the figure that the overall distribution of the green water footprint of the three crops was higher in the east than it was in the west. However, the distribution of green water footprint was somewhat different for each crop. Wheat had the largest green water footprint in Wuyuan $\left(197 \mathrm{~m}^{3} \mathrm{t}^{-1}\right)$ and the lowest in Dengkou $\left(132 \mathrm{~m}^{3} \mathrm{t}^{-1}\right)$. Corn had the largest green water footprint in Wulate Qianqi $\left(186 \mathrm{~m}^{3} \mathrm{t}^{-1}\right)$ and the lowest in Hangjin Houqi $\left(119 \mathrm{~m}^{3} \mathrm{t}^{-1}\right)$, but in Dengkou, it was approximately equal to that in Linhe, ranging from 133 to $139 \mathrm{~m}^{3} \mathrm{t}^{-1}$. Sunflowers had the largest green water footprint in Wulate Qianqi $\left(538 \mathrm{~m}^{3} \mathrm{t}^{-1}\right)$ and the lowest in Linhe $\left(325 \mathrm{~m}^{3} \mathrm{t}^{-1}\right)$.

\subsection{The regional blue-water footprint of crop production}

The blue water footprint of the crops is produced by blue water that is consumed during crop growth. The blue water consumption during crop growth mainly includes the loss during transportation, actual ET and field drainage. Figure 8 shows the spatial variability of wheat, corn and sunflowers in HID. The overall distribution of the total water footprint of the three crops was higher in the east than in the west and higher in the north than in the south. However, the specific distribution was somewhat different for each crop. Wheat had the largest blue water footprint in Wulate Qianqi $\left(2714 \mathrm{~m}^{3} \mathrm{t}^{-1}\right)$ and the lowest in southern Linhe $\left(1233 \mathrm{~m}^{3} \mathrm{t}^{-1}\right)$. Corn had the largest blue water footprint in northern Wulate Qianqi $\left(1588 \mathrm{~m}^{3} \mathrm{t}^{-1}\right)$ and the lowest in southern Hangjin Houqi $\left(820 \mathrm{~m}^{3} \mathrm{t}^{-1}\right)$. Sunflowers had the largest blue water footprint in northern Wulate Qianqi $\left(4317 \mathrm{~m}^{3} \mathrm{t}^{-1}\right)$ and the lowest in southern Linhe $\left(1765 \mathrm{~m}^{3} \mathrm{t}^{-1}\right)$.

\subsection{The regional total-water footprint of crop production}

The total water footprint of crop production consists of both blue and green water footprints during the crop growth period. Figure 9 shows the total water footprint of crop production and spatial variability of wheat, corn, and sunflowers in HID. The overall distribution of the total water footprint of the three crops was higher in the east (Wulate Qianqi and 

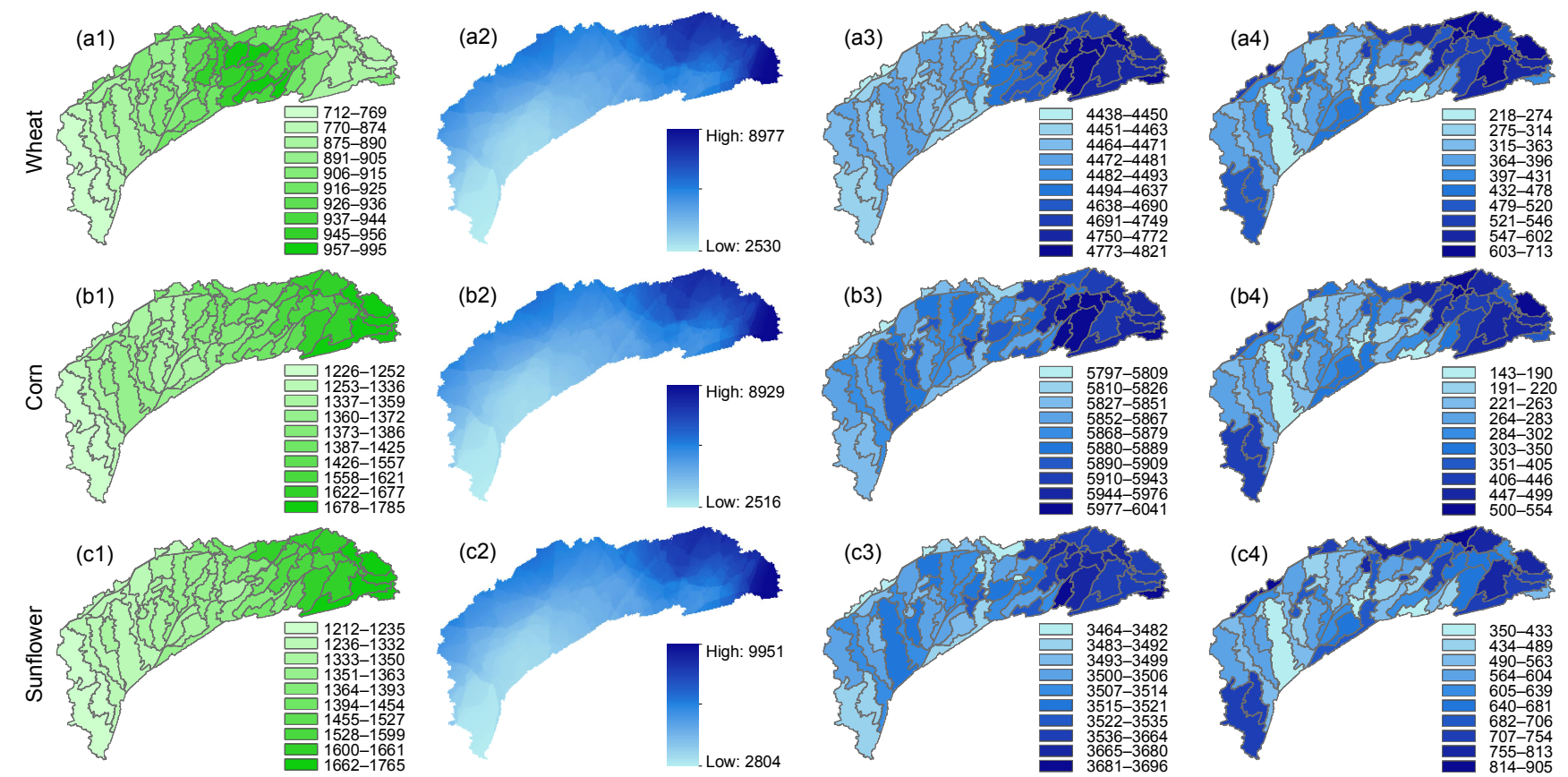

Canal water loss

Field irrigation water ET

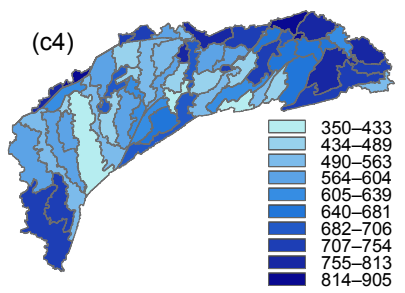

Field discharge

Figure 6. Spatial distribution of the different water consumption of three crops $\left(\mathrm{m}^{3} \mathrm{ha}^{-1}\right)$.
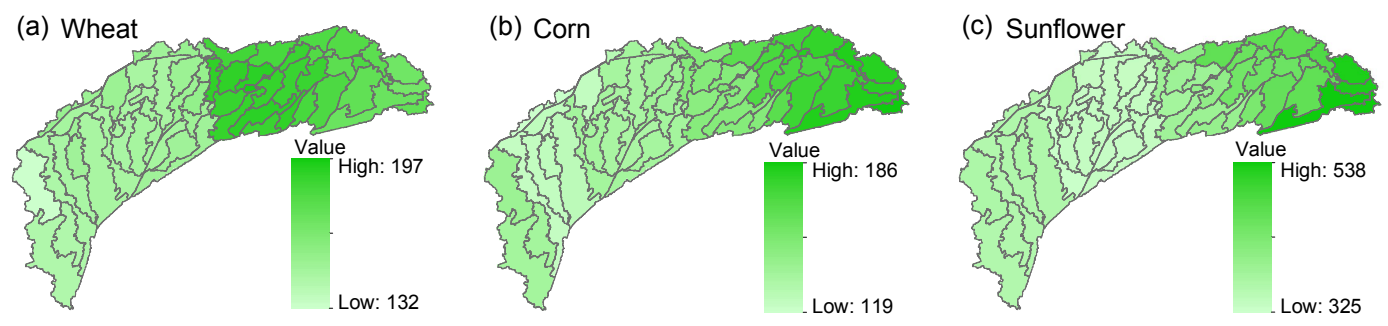

Figure 7. The spatial distribution of the green water footprint of crop production in the HID $\left(\mathrm{m}^{3} \mathrm{t}^{-1}\right)$.
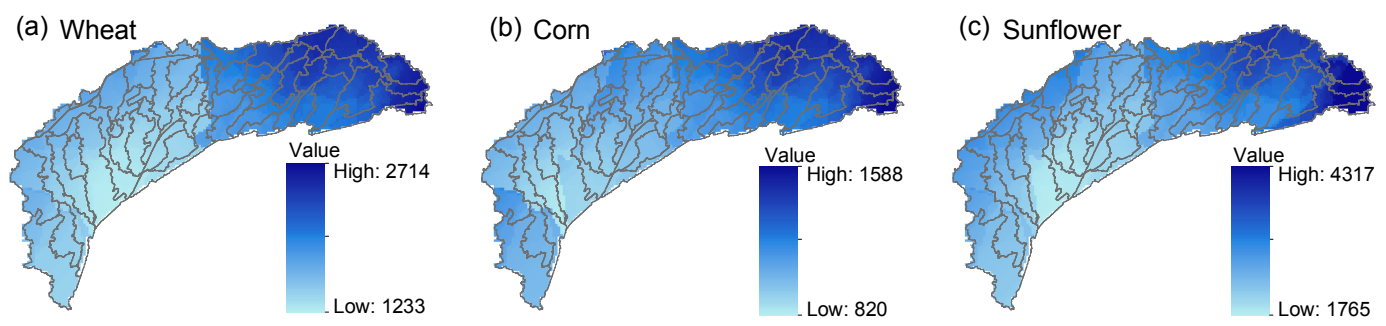

Figure 8. The spatial distribution of the blue water footprint of crop production in the HID $\left(\mathrm{m}^{3} \mathrm{t}^{-1}\right)$.

Wuyuan) than it was in the west (Dengkou), followed by the central region (Hangjin Houqi and Linhe), and it was higher in the north than in the south. However, the specific distribution was somewhat different for each crop. Wheat had the largest total water footprint in the east (Wulate Qianqi, $\left.2888 \mathrm{~m}^{3} \mathrm{t}^{-1}\right)$ and the lowest in southern Linhe $\left(1380 \mathrm{~m}^{3} \mathrm{t}^{-1}\right)$. Corn had the largest total water footprint in the east $(\mathrm{Wu}-$ late Qianqi, $1774 \mathrm{~m}^{3} \mathrm{t}^{-1}$ ) and the lowest in southern Hangjin
Houqi $\left(942 \mathrm{~m}^{3} \mathrm{t}^{-1}\right)$. Sunflowers had the largest total water footprint in the east (Wulate Qianqi, $4855 \mathrm{~m}^{3} \mathrm{t}^{-1}$ ) and the lowest value was in southern Linhe $\left(2095 \mathrm{~m}^{3} \mathrm{t}^{-1}\right)$. The total water footprint of crop production also varied across crops. The largest of the average total water footprint in the HID was the sunflower, followed by wheat and corn. The blue water footprint of wheat, corn and sunflowers accounted for $89 \%, 87 \%$ and $86 \%$ of the total water footprint, respectively. 

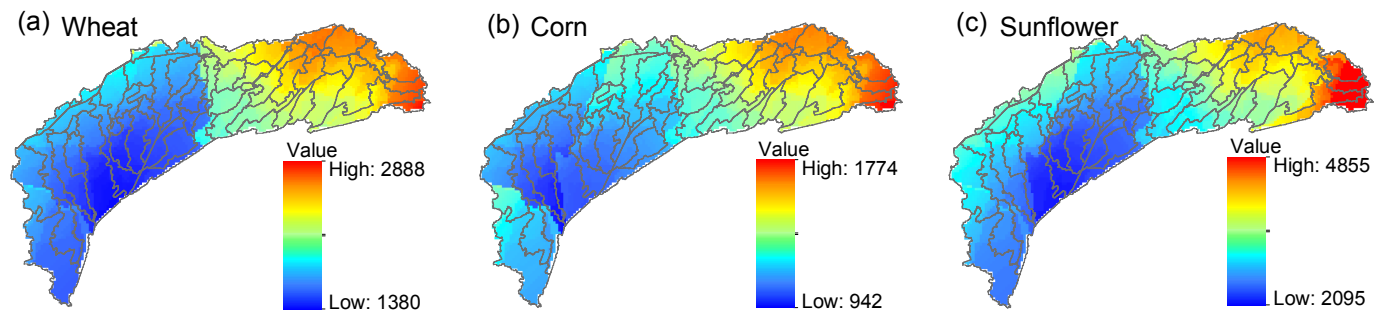

Figure 9. The spatial distribution of the total water footprint of crop production in the HID $\left(\mathrm{m}^{3} \mathrm{t}^{-1}\right)$.

\section{Discussion}

\subsection{The regional-scale and field-scale methods for calculating crop production water footprint}

In this paper, the calculation method for calculating the crop production water footprint is divided into the field-scale and regional-scale method, according to the calculation boundary of water consumption in the crop growth process. The field-scale water footprint is composed of the transpiration of crops and the evaporation of soil, and the water loss during transportation is not included. The regional-scale water footprint calculation method considers all of the water consumption related to crop growth from the water source to the field. It not only includes the ET from the field but also the water loss during transportation in the canal system and the water loss discharged out of the region.

Currently, irrigated farmland occupies $39.6 \%$ of the total arable land in China (NBSC, 2016). Globally, irrigated area account for $20.6 \%$ of all arable land (FAO, 2016). Overall, the yields of irrigation agriculture are much higher than those of rain-fed agriculture. Figure 10 illustrates the water sources and use conditions of two types of agriculture. In irrigated agriculture, water (blue water) goes through the following processes from water source to field; these are water diversion, water transportation (canal system or pipeline) and different methods (surface irrigation, sprinkler irrigation, drip irrigation, etc.) to irrigate crops and excess water discharged from the field. In irrigated agricultural production, especially in areas where water is transported through channels for irrigation, a large amount of water is lost (canal leakage or water evaporation) during the transportation process, which is indirectly used for crop production. The transportation process generates large costs (energy, machinery, facilities, management, etc. for water diversion). Therefore, this water loss is also a part of the crop production water footprint. In China, the irrigation water consumption was $360 \times 10^{9} \mathrm{~m}^{3}$, and the effective utilization coefficient of irrigation water was 0.53 (MWR, 2015), which indicated that about $169.2 \times 10^{9} \mathrm{~m}^{3}$ of water resources were lost in the process of transportation and irrigation. It is necessary to include the amount of blue water loss during irrigation into the crop production water footprint. Figure 11 is the calculation range of the regional

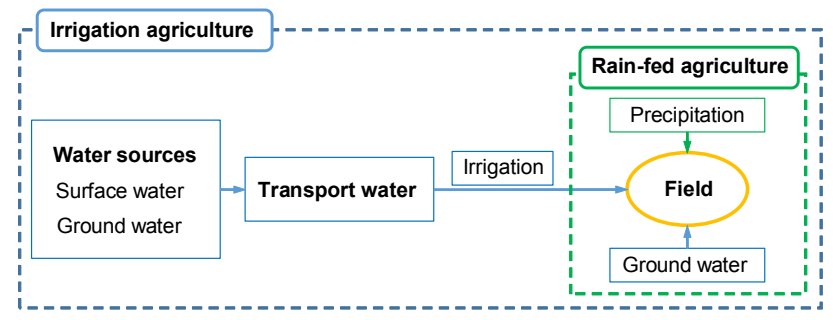

Figure 10. Irrigation agriculture and rain-fed agriculture.

-scale and field-scale methods of crop production water footprint. Consequently, the calculation method on regional scale can comprehensively calculate the total water consumption in the crop production process, and the calculated results of the water footprint are more accurate, while the field -scale method only calculates part of the water consumption in the process (Zhao et al., 2009; Bocchiola, 2015). At the same time, the calculation method on the regional scale proposed in this study improves the resolution of the water footprint results. It can also reflect the variation of the water footprint within the region, more effectively discover the water footprint hotspots and avoid the shortcomings that can only reflect the mean value of the regional results due to a low resolution (Vanham and Bidoglio, 2013; Zhuo et al., 2016). These two advantages of the regional -scale approach can help local authorities to develop more rational water allocation and management policies.

\subsection{Comparison of the results of two methods}

For the field-scale method, the calculated value was less than the actual value, because it did not consider the loss of water during transportation or discharge, and the actual water footprint of irrigation agriculture cannot be precisely assessed. At present, most studies use the field-scale method (e.g. CROPWAT model) (Lovarelli et al., 2016), so these studies mainly focus on agricultural water use at field scale, lacking an analysis of the entire process of agricultural production water use, which is also the shortcoming of the current research on the crop production water footprint. Therefore, using the regional-scale method to calculate the crop water footprint, especially in irrigation agriculture, is the basis for a compre- 


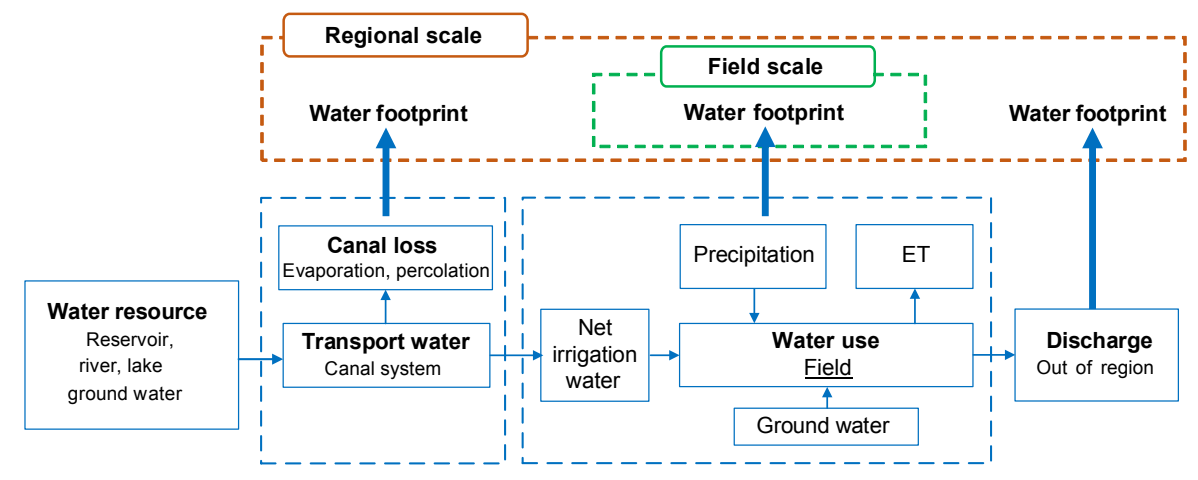

Figure 11. The different scales of calculating water footprint.

hensive and accurate evaluation of a crop production water footprint in China and other regions or countries.

In HID, the water footprint of three crops (wheat, corn and sunflowers) calculated by the regional-scale method were 1380-2888, 942-1774, and 2095-4855 $\mathrm{m}^{3} \mathrm{t}^{-1}$, respectively. These values were higher than the results calculated by the field-scale method. Cao et al. (2014) calculated the average crop water footprint of irrigation agriculture in China from 1998 to 2010, and the average value of many crops in the Inner Mongolia autonomous region (including HID) was $1556 \mathrm{~m}^{3} \mathrm{t}^{-1}$. Sun et al. (2013b) calculated the average water footprint of HID by using the regional-scale method and water balance principle, and the result was $3910 \mathrm{~m}^{3} \mathrm{t}^{-1}$. The proportion of blue water and green water was $90.9 \%$ and $9.1 \%$, respectively. This result was the average water footprint of many crops, and the value was approximate to our results. Qin et al. (2016) calculated the water footprints of sunflowers in the Jilin province by using the field-scale method and found that the water footprint of sunflowers in this area from 2006 to 2008 were 1280,1684 and $1726 \mathrm{~m}^{3} \mathrm{t}^{-1}$, respectively, which was smaller than this study. This is because Jilin's water footprint is mainly composed of green water footprint, which reached $95 \%$, and its blue water footprint is smaller. In addition, these studies all showed the water footprint of the region, which cannot distinguish the spatial distribution of the crop production water footprint within the region and has a limited impact on the improvement of local water resource management.

This method also has limitations. The method requires more data types (e.g. DEM, land use, soil data, climate data, hydrological data and crop management data), and higher data resolution. Therefore, the method is not applicable to areas where the above data are lacking.

\subsection{Strategies for adjusting the crop production water footprint}

The water footprint of crop production is affected by crop species. Different crops have different water use characteristics and different growth periods. Therefore, adjusting the crop planting structure can change the water supply in the region (Fasakhodi et al., 2010), which in turn affects the water footprint of crop production. At the same time, changing the crop pattern and planting crops whose growth periods are consistent with the precipitation period can increase the utilization of green water, reduce the consumption of blue water and reduce the pressure on local water resources (Liu et al., 2018). This study found that in the HID, the growth period of sunflowers is basically the same as the precipitation period. Consequently, expanding the planting area of sunflowers can make better use of local precipitation resources and reduce the use of blue water.

The crop yield is an important factor affecting the water footprint of crop production. Selecting crop varieties with high yields and improving agricultural management measures play an important role in increasing crop yields. Sun et al. (2013b) found that improving agricultural management measures is an important factor in increasing crop yield and reducing the water footprint of crop production. Liu et al. $(2014,2015)$ discussed the water use situation and virtual water flow in the Hetao irrigation district and found that crop yield had an important impact on the water footprint of crop production, and with the increasing of the crop yield per unit area, the water footprint of crop production had declined.

The efficiency of the irrigation system is affected by the way of water transportation, the condition of the canal system, the irrigation technology and so on. Therefore, the water use efficiency of the regional irrigation system can be improved by changing the water delivery method (from the channel to the pipeline) and the irrigation method (such as the dropper, sprinkler and other advanced irrigation technologies). For the study area, the results show that more than half of the water resources were lost during the process of canal water transport and irrigation. Therefore, adopting antiseepage measures to reduce the leakage of the canal system and adopting advanced irrigation technology to reduce the amount of irrigation water will help to reduce the water footprint of crop production in this region. 


\section{Conclusions}

In this study, we proposed an improved regional-scale method for calculating the crop production water footprint. This method was based on the hydrological model (SWAT model), combined the irrigation parameters of the irrigation area (water conveyance efficiency of the canal) and calculated the crop production water footprint.

The method provided a whole hydrological processes analysis for water use during crop production, including water diversion, irrigation and precipitation, field evapotranspiration and drainage. Therefore, the method contributed to the establishment of a more comprehensive calculation of water consumption during the crop growth period and a more precisely quantification of the crop production water footprint. The method can be applied to calculate the crop production water footprint at both the field and regional scale. In the HID, the main water consumption occurs during the crop growth period; the canal water loss was $1652 \times 10^{6} \mathrm{~m}^{3}$, and actual ET in the field was $1442 \times 10^{6} \mathrm{~m}^{3}$, which accounted for $47.9 \%$ and $41.8 \%$ of the total used, respectively.

The regional climate, the condition of the irrigation system and the crop yield are the main factors that affect the water footprint of crop production. The area with higher crop yield per unit area, higher efficiency of irrigation water use, less irrigation water loss and closer to source of water has a lower crop production water footprint. Water loss during transportation increased with the increasing distance of the canals, and the farther away from the watershed inlets they were, the more water was lost; the values were higher in the east than they were in the west in the study area.

Due to special climatic conditions, crops in the Hetao irrigation district mainly depend on irrigation water in the production process. Overall, in the composition of the water footprint in the Hetao irrigation district, the blue water footprint accounts for more than $86 \%$. Therefore, applying water-saving irrigation technology, increasing the channel lining rate and reducing the loss of irrigation water are the main ways to adjust and control the water footprint of crop production in this area.

Based on the SWAT model, this paper analysed the utilization and consumption of water resources during crop production in irrigated areas, which provided a hydrological mechanism for quantifying the water footprint of crop production. However, the SWAT model does not consider the relation of groundwater flow between different sub basins. At the same time, the shallow groundwater evaporation is based on the soil as a medium, and directly into the atmosphere, the model cannot accurately quantify the recharge of shallow groundwater to soil water. Consequently, the SWAT model cannot accurately simulate the shallow groundwater consumption of crops. Therefore, combining the groundwater model, analysing the flow of water in the process of regional agricultural production and then quantifying the water footprint of crop production is the direction of further research.
Data availability. The DEM data used in this study were obtained from the Geospatial Data Cloud site, Computer Network Information Center, Chinese Academy of Sciences (http://www.gscloud.cn, CAS, 2009a). The soil data used in this study were obtained from the China Soil Scientific Database, Soil Research Center, Institute of Soil Science, Chinese Academy of Sciences (http://www.soil. csdb.cn/, CAS 2009b). The land use data used in this study were obtained from the Data Center for Resources and Environmental Sciences, Chinese Academy of Sciences (http://www.resdc.cn, CAS, 2010). The meteorological data used in this study were obtained from the China Meteorological Data Service Center (http: //data.cma.cn, NMIC, 2015). The hydrologic data and the crop parameter data used in this study were obtained from the Administration of Hetao irrigation district (http://www.htgq.gov.cn/, AHID, 2015). Other data is cited in references in this paper. The data of the study are available from the authors upon request.

Supplement. The supplement related to this article is available online at: https://doi.org/10.5194/hess-22-5111-2018-supplement.

Author contributions. PTW, SKS and YBW designed the study. XBL, YLY, XRG and JL did the literature search and data collection. XBL, SKS and YLY managed and analysed the data. XBL and SKS drew the figures and wrote the paper. All authors discussed and commented on the manuscript.

Competing interests. The authors declare that they have no conflict of interest.

Special issue statement. This article is part of the special issue "Integration of Earth observations and models for global water resource assessment". It is not associated with a conference.

Acknowledgements. This work is jointly supported by the National Natural Science Foundation of China (51409218; 51609063), Innovative Talents Promotion Project in Shaanxi Province of China (2018KJXX-053), the Open Research Fund of the State Key Laboratory of Simulation and Regulation of Water Cycle in River Basin at the China Institute of Water Resources and Hydropower Research (IWHR-SKL-201601) and the Young Scholar Project of the Cyrus Tang Foundation.

Edited by: Martina Floerke

Reviewed by: two anonymous referees

\section{References}

Abbaspour, K. C.: SWAT-CUP 2012: SWAT Calibration and Uncertainty Programs - A User Manual, Eawag: Swiss Federal Institute Science and Technology, available at: https://swat.tamu.edu/ media/114860/usermanual_swatcup.pdf (last access: 15 November 2016), 2012. 
Abbaspour, K. C., Vejdani, M., and Haghighat S.: SWAT-CUP calibration and uncertainty programs for SWAT, in: Modsim 2007: International Congress on Modelling and Simulation: Land, Water and Environmental Management: Integrated Systems for Sustainability, Christchurch, New Zealand, 2007.

AHID - Administration of Hetao Irrigation District: Bayannaoer Department of Water, Inner Mongolia Autonomous Region, China, available at: http://www.htgq.gov.cn/, last access: 5 September 2015.

Allen, R. G., Pereira, L. S., Raes, D., and Smith, M.: Crop evapotranspiration: Guidelines for computing crop water requirements, FAO Irrigation and Drainage Paper 56, FAO, Rome, 1998.

Bao, C. and Fang, C.: Water Resources Flows Related to Urbanization in China: Challenges and Perspectives for Water Management and Urban Development, Water Resour. Manage., 26, 531-552, https://doi.org/10.1007/s11269-011-9930-y, 2012.

Bocchiola, D.: Impact of potential climate change on crop yield and water footprint of rice in the Po valley of Italy, Agr. Syst., 139, 223-237, https://doi.org/10.1016/j.agsy.2015.07.009, 2015.

Bocchiola, D., Nana, E., and Soncini, A.: Impact of climate change scenarios on crop yield and water footprint of maize in the Po valley of Italy, Agr. Water Manage., 116, 50-61, https://doi.org/10.1016/j.agwat.2012.10.009, 2013.

Cao, X., Wu, P., Wang, Y., and Zhao, X.: Water Footprint of Grain Product in Irrigated Farmland of China, Water Resour. Manage., 28, 2213-2227, https://doi.org/10.1007/s11269-014-0607$1,2014$.

CAS: Geospatial Data Cloud site (GSCloud), Computer Network Information Center, Chinese Academy of Sciences, available at: http://www.gscloud.cn (last access: 10 August 2016), 2009a.

CAS: China Soil Scientific Database (CSDB), Soil Research Center, Institute of Soil Science, Chinese Academy of Sciences, available at: http://www.soil.csdb.cn/ (last access: 12 August 2016), 2009b.

CAS: Data Center for Resources and Environmental Sciences (RESDC), Chinese Academy of Sciences, available at: http://www.resdc.cn (last access: 23 August 2016), 2010.

Chen, J.: Rapid urbanization in China: a real challenge to soil protection and food security, Catena, 69, 1-15, https://doi.org/10.1016/j.catena.2006.04.019, 2007.

Chukalla, A. D., Krol, M. S., and Hoekstra, A. Y.: Green and blue water footprint reduction in irrigated agriculture: effect of irrigation techniques, irrigation strategies and mulching, Hydrol. Earth Syst. Sci., 19, 4877-4891, https://doi.org/10.5194/hess-19-48772015, 2015.

Deng, X. P., Shan, L., Zhang, H., and Turner, N. C.: Improving agricultural water use efficiency in arid and semiarid areas of China, Agr. Water Manage., 80, 23-40, https://doi.org/10.1016/j.agwat.2005.07.021, 2006.

Doll, P. and Siebert, S.: Global modeling of irrigation water requirements, Water Resour. Res., 38, 1037-1048, https://doi.org/10.1029/2001WR000355, 2002.

Du, T., Kang, S., Zhang, X., and Zhang, J.: China's food security is threatened by the unsustainable use of water resources in North and Northwest China, Food Energy Secur., 3, 7-18, https://doi.org/10.1002/fes3.40, 2014.

Duh, J., Shandas, V., Chang, H., and George, L. A.: Rates of urbanisation and the resiliency of air and water quality, Sci. Total Environ., 400, 238-256, https://doi.org/10.1016/j.scitotenv.2008.05.002, 2008.

Elliott, J., Deryng, D., Muller, C., Frieler, K., Konzmann, M., Gerten, D., Glotter, M., Flörke, M., Wada, Y., Best, N., Eisner, S., Fekete, B. M., Folberth, C., Foster, I., Gosling, S. N., Haddeland, I., Khabarov, N., Ludwig, F., Masaki, Y., Olin, S., Rosenzweig, C., Ruane, A. C., Satoh, Y., Schmid, E., Stacke, T., Tang, Q. H., and Wisser, D.: Constraints and potentials of future irrigation water availability on agricultural production under climate change, P. Natl. Acad. Sci. USA., 111, 3239-3244, https://doi.org/10.1073/pnas.1222474110, 2014.

FAO - Food and Agriculture Organization of the United Nations: Land and Water Development Division, CROPWAT model, Rome, Italy, http://www.fao.org/land-water/ databases-and-software/cropwat/en/ (last access: 25 September 2016), 2010.

FAO: AQUASTAT website, Food and Agriculture Organization of the United Nations, available at: http://www.fao.org/nr/ water/aquastat/data/query/index.html, (last access: 20 September 2017), 2016.

Fasakhodi, A. A., Nouri, S. H., and Amini, M.: Water resources sustainability and optimal cropping pattern in farming systems: a multi-objective fractional goal programming approach, Water Resour. Manage., 24, 4639-4657, https://doi.org/10.1007/s11269-010-9683-z, 2010.

Haddeland, I., Heinke, J., Biemans, H., Eisner, S., Flörke, M., Hanasaki, N., Konzmann, M., Ludwig, F., Masaki, Y., Schewe, J., Stacke, T., Tessler, Z. D., Wada, Y., and Wisser, D.: Global water resources affected by human interventions and climate change, P. Natl. Acad. Sci. USA., 111, 3251-3256, https://doi.org/10.1073/pnas.1222475110, 2014.

Haverkamp, S., Srinivasan, R., Frede, H. G., and Santhi, C.: Subwatershed spatial analysis tool: discretization of a distributed hydrologic model by statistical criteria, J. Am. Water Resour. Assoc., 38, 1723-1733, https://doi.org/10.1111/j.17521688.2002.tb04377.x, 2002.

Hoekstra, A. Y. (Ed.): Virtual water trade, in: Proceedings of the International Expert Meeting on Virtual Water Trade, 1213 December 2002, Value of Water Research Report Series No. 12, UNESCO-IHE, Delft, the Netherlands, available at: http: //waterfootprint.org/media/downloads/Report12.pdf (last access: 22 August 2016), 2003.

Hoekstra, A. Y., Chapagain, A. K., Aldaya, M. M., and Mekonnen, M. M.: The water footprint assessment manual-setting the global standard, Earthscan, London, Washington, 2011.

Jiang, Y.: China's water scarcity, J. Environ. Manage., 90, 3185 3196, https://doi.org/10.1016/j.jenvma n.2009.04.016, 2009.

Khan, S., Hanjra, M. A., and Mu, J. X.: Water management and crop production for food security in China: a review, Agr. Water Manage., 96, 349-360, https://doi.org/10.1016/j.agwat.2008.09.022, 2009.

Liu, J., Yang, H., and Savenije, H. H.: China's move to higher-meat diet hits water security, Nature, 454, p. 397, https://doi.org/10.1038/454397a, 2008.

Liu, J., Wu, P., Wang, Y., Zhao, X., Sun, S., and Cao, X.: Impacts of changing cropping pattern on virtual water flows related to crops transfer: a case study for the Hetao irrigation district, China, J. Sci. Food Agr., 94, 2992-3000, https://doi.org/10.1002/jsfa.6645, 2014. 
Liu, J., Sun, S., Wu, P., Wang, Y., and Zhao, X.: Evaluation of crop production, trade, and consumption from the perspective of water resources: A case study of the Hetao irrigation district, China, for 1960-2010, Sci. Total Environ., 505, 1174-1181, https://doi.org/10.1016/j.scitotenv.2014.10.088, 2015.

Liu, J., Cao, X., Li, B., and Yu, Z.: Analysis of blue and green water consumption at the irrigation district scale, Sustainability-Basel, 10, 305, https://doi.org/10.3390/su10020305, 2018.

Liu, J. G., Williams J. R., Zehnder, A. J. B., and Hong, Y.: GEPIC-modelling wheat yield and crop water productivity with high resolution on a global scale, Agr. Syst., 94, 478-493, https://doi.org/10.1016/j.agsy.2006.11.019, 2007.

Lovarelli, D., Bacenetti, J., and Fiala, M.: Water footprint of crop productions: a review, Sci. Total Environ., 548-549, 236-251, https://doi.org/10.1016/j.scitotenv.2016.01.022, 2016.

Luan, X. B., Wu, P. T., Sun, S. K., Wang, Y. B., and Gao, X. R.: Quantitative study of the crop production water footprint using the SWAT model, Ecol. Indic., 89, 1-10, https://doi.org/10.1016/j.ecolin d.2018.0 1.046, 2018.

Mekonnen, M. M. and Hoekstra, A. Y.: The green, blue and grey water footprint of crops and derived crop products, Hydrol. Eath Syst. Sci., 15, 1577-1600, https://doi.org/10.5194/hess-15-15772011, 2011.

MWR - Ministry of Water Resources People's Republic of China: China water resources bulletin 2014, China Water and Power Press, Beijing, 2015.

NBSC - National Bureau of Statistics of China: China Statistical Yearbook 2016, China Statistics Press, Beijing, 2016.

Neitsch, S. L., Arnold, J. G., Kiniry, J. R., and Williams, J. R.: Soil and Water Assessment Tool: Theoretical Documentation, Version 2009, Texas Water Resources Institute, available at: https: //swat.tamu.edu/media/99192/swat2009-theory.pdf (last access: 12 November 2016), 2011.

Nijssen, B., Odonnell, G. M., Hamlet, A. F., and Lettenmaier, D. P.: Hydrologic Sensitivity of Global Rivers to Climate Change, CLIMATIC CHANGE, 50, 143-175, https://doi.org/10.1023/A:1010616428763, 2001.

NMIC: China meteorological data network (CMA), National Meteorological Information Center, China, available at: http://data. cma.cn/ (last access: 23 December 2016), 2015.

Pasquale, S., Theodorec, H., Dirk, R., and Elias, F.: Aquacropthe FAO crop model to simulate yield response to water: I. concepts and underlying principles, Agron. J., 101, 448-459, https://doi.org/10.2134/agronj2008.0139s, 2009.

Piao, S., Ciais, P., Huang, Y., Shen, Z., Peng, S., Li, J., Zhou, L., Liu, H., Ma, Y., Ding, Y., Friedingstein, P., Liu, C., Tan, K., Yu, Y., Zhang, T., and Fang, J.: The impacts of climate change on water resources and agriculture in China, Nature, 467, 43-51, https://doi.org/10.1038/nature09364, 2010.

Qin, L., Jin, Y., Duan, P., and He, H.: Field-based experimental water footprint study of sunflower growth in a semiarid region of China, J. Sci. Food Agr., 96, 3266-3273, https://doi.org/10.1002/jsfa.7726, 2016.
Schwarzenbach, R. P., Egli, T., Hofstetter, T. B., Von Gunten, U., and Wehrli, B.: Global water pollution and human health, Annu. Rev. Environ. Resour., 35, 109-136, https://doi.org/10.1146/ann urev-environ-100809-125342, 2010.

Shi, R., Ukaew, S., Archer, D. W., Lee, J. H., Pearlson, M. N., Lewis, K. C., and Shonnard, D. R.: Life Cycle Water Footprint Analysis for Rapeseed Derived Jet Fuel in North Dakota, ACS Sustain. Chem. Eng., 5, 3845-3854, https://doi.org/10.1021/acssuschemeng.6b02956, 2017.

Shiklomanov, I. A.: Appraisal and assessment of world water resources, Water Int., 25, 11-32, https://doi.org/10.1080/02508060008686794, 2000.

Sun, S. K., Wu, P. T., Wang, Y. B., and Zhao, X. N.: Temporal variability of water footprint for maize production: the case of Beijing from 1978 to 2008, Water Resour. Manage., 27, 2447-2463, https://doi.org/10.1007/s11269-013-0296-1, 2013a.

Sun, S. K., Wu, P. T., Wang, Y. B., Zhao, X. N., Liu, J., and Zhang, X.: The impacts of inter-annual climate variability and agricultural inputs on water footprint of crop production in an irrigation district of China, Sci. Total Environ., 444, 498-507, https://doi.org/10.1016/j.scitoten v.2012.12.016, 2013 b.

Sun, S. K., Wu, P. T., Wang, Y. B., and Zhao, X. N.: The virtual water content of major grain crops and virtual water flows between regions in China, J. Sci. Food Agr., 93, 1427-1437, https://doi.org/10.1002/jsfa.5911, 2013c.

Vanham, D. and Bidoglio, G.: A review on the indicator water footprint for the EU28, Ecol. Indic., 26, 61-75, https://doi.org/10.1016/j.ecolind.2012.10.021, 2013.

Vörösmarty, C. J., Mcintyre, P. B., Gessner, M. O., Dudgeon, D., Prusevich, A., Green, P., Glidden, S., Bunn, S. E., Sullivan, C. A., Reidy Liermann, C., and Davies P. M.: Global threats to human water security and river biodiversity, Nature, 467, 555-561, https://doi.org/10.1038/nature09440, 2010.

Wang, Y. B., Wu, P. T., Zhao, X. N., and Engel, B. A.: Virtual water flows of grain within China and its impact on water resource and grain security in 2010, Ecol. Eng., 69, 255-264, https://doi.org/10.1016/j.ecoleng.2014.03.057, 2014.

Zhao, X., Chen, B., and Yang, Z. F.: National water footprint in an input-output framework - a case study of China 2002, Ecol. Model., 220, 245-253, https://doi.org/10.1016/j.ecolmodel.2008.09.016, 2009.

Zhuo, L., Mekonnen, M. M., and Hoekstra, A. Y.: Benchmark levels for the consumptive water footprint of crop production for different environmental conditions: a case study for winter wheat in China, Hydrol. Earth Syst. Sci., 20, 4547-4559, https://doi.org/10.5194/hess-20-4547-2016, 2016. 